\title{
A MIDDLE ENGLISH VERSE COMPENDIUM OF ASTROLOGICAL MEDICINE
}

by

\author{
LINNE R. MOONEY*
}

IN late medieval England, the number of persons literate in the vernacular was growing rapidly. ${ }^{1}$ The same interest in self-improvement which led these people to learn to read also led them to seek out, or to sponsor the production of, works that would make available to them knowledge from both antique and earlier medieval sources - knowledge to which as yet, for the most part, only those who could read Latin had access. The broad and growing interest in such reading matter must have occasioned the composition in, or translation to, the vernacular of the many works of medical, scientific, and practical knowledge which survive from the fifteenth century. ${ }^{2}$ In a recent article in Medical History, Faye Marie Getz has examined the Middle English translations of Latin medical texts, concluding that "... Middle English medical literature ... [provided] vernacular access to the best of contemporary Latin medicine, through translations, excerpts and paraphrases."3 The Middle English work on astrological medicine edited below offers evidence of another method by which the received knowledge of medieval medicine was rendered into the vernacular, through the compilation of excerpts, paraphrases, and translations from several sources, loosely held together in rhyme. Before turning to this aspect of the work, however, a brief description of the surviving texts will be necessary.

The Middle English verse compendium of astrological medicine survives in two manuscripts of the late fourteenth and early fifteenth centuries: Bodleian Library, Ashmole 210, Part I (Summary Catalogue 6795), on folio 9r, and British Library, Sloane 610 , on folios $5^{r}$ to $6^{r}$. The 110 -line poem is unpublished, except for ten lines from the Sloane version edited by T. J. Pettigrew in $1844 ;{ }^{4}$ and, indeed, it has only recently been recognized as a distinct poem, for these two manuscript versions were listed with poems dealing only with bloodletting under number 3848 in the Index of Middle English verse and its Supplement. ${ }^{5}$ The verses bring together instruction in the

*Linne R. Mooney, PhD, Department of English, University of Maine, Orono, Maine 04469, USA.

${ }^{1}$ Malcolm Parkes, 'The literacy of the laity', in David Daiches and Anthony Thorlby (editors), The medieval world, London, Aldus Books, 1973, pp. 558-560.

${ }^{2}$ H. S. Bennett, 'Science and information in English writings of the fifteenth century', Modern Language Review, 1944, 39: 1-8; and Rossell Hope Robbins, 'Medical manuscripts in Middle English', Speculum. 1970, 45: 393-415.

${ }^{3}$ Faye Marie Getz, 'Gilbertus Anglicus anglicized', Med. Hist., 1982, 26: 436-442.

-T. J. Pettigrew, 'Observations upon the extracts from an Ancient English medical manuscript in the Royal Library of Stockholm', Archaeologia, 1844, 30: 420.

s Carleton Brown and Rossell Hope Robbins (editors), The index of Middle English verse. New York, Columbia University Press, 1943 (hereinafter IMEV); and Rossell Hope Robbins and John L. Cutler (editors), Supplement to the index of Middle English verse, Lexington, University of Kentucky Press, 1965 (hereinafter IMEVS). I have distinguished three poems from those listed under number 3848 in $I M E V$ and 


\section{A Middle English verse compendium of astrological medicine}

influences of the four elements, four humours, and the signs of the zodiac upon man, and in the perilous days for bloodletting and location of veins to be opened for specific ailments. Because of the composite characteristic of this poem, I shall refer to it as the "Compendium of astrological medicine" or the "Compendium".

Ashmole 210 (hereinafter A) brings together five medieval and early modern manuscripts under one cover. The "Compendium" occurs in the first of these, a kalendar of the end of the fourteenth century, with medical texts appended. Its contents, as listed by Black, ${ }^{6}$ include a volvelle (f. 17 ), the Kalendarium of Richard Thorpe, with tables of solar and lunar eclipses for the years 1386-1460 (ff. 2 -7 y), tables of moveable feasts and bissextiles, that on folio $8^{v}$ headed "Regule Eboracensis" (f. $8^{\text {r- }}$ ), "Zodiac Man" with a Latin rule for phlebotomy above it and the "Compendium" in columns on either side ( $f .97$ ), lunar tables of the signs, angles, and ruling planets of each day (ff. $9^{v}-10^{v}$, a table of "Flebothomie" by John de Mirapice (f. 11 ), and "Vein Man" (f. 11 ).

All of the tables and texts on folios $1^{\mathrm{r}}$ to $11^{\mathrm{v}}$ were written by one hand of the late fourteenth century, except for the rules on folio $8^{v}$, which were added in the fifteenth century. The main scribe writes in a very small, vertical Anglicana, using Textura Semi-quadrata for display script on some of the tables, particularly those on folios 8 , $9^{v}$ and $10^{r-v}$. The rules on $8^{v}$ are added by a loose, current hand of the fifteenth century. In his description of the manuscript, William Black suggests that the "Compendium" was also added in the fifteenth century, ${ }^{8}$ but it appears to be written in a hand contemporaneous with the main scribe, if not by the main scribe himself, using a slightly different style for vernacular poetry than for Latin prose, just as he uses different styles for display and prose texts. The text of the "Compendium" is written in columns on either side of the figure. Between them, above the figure, is a Latin rule for phlebotomy, written in the hand of the main scribe. The first column of the "Compendium" extends, in some lines, into the second column of the page; and in those lines, the text of the Latin rule has been moved to the right, away from its usual left margin. The left margin of column c, the second half of the "Compendium", is not broken by intrusion of the Latin rule in column b. It appears, then, that the "Compendium" was written before the Latin rule, and therefore can be dated as contemporary with the main hand of the manuscript.

IMEVS; see numbers 3074.4 (verses edited here), 3848, and 4264.2 in 'Additions and emendations to The index of Middle English verse and its Supplement', Anglia, 1981, 99: 396-398.

- William H. Black, A . . catalogue of the MSS bequeathed ... by Elias Ashmole. Part X of W. D. Macray (editor), Catalogi codicum manuscriptorum Bibliothecae Bodleianae, Oxford, Clarendon Press, 1845, col. 172.

'See item 3 in Black's description. The kalendar author, "Frater Ricardus Thorppus Augustinensis", can scarcely be the same Richard Thorpe whom A. B. Emden ( $A$ biographical register of the University of Oxford to AD 1500, 3 vols., Oxford, Clarendon Press, 1957-59, vol. 3, 1869) identifies as Fellow of Queen's College in 1377 and Rector of Hampton Poyle, Oxon, in 1393. The Richard Thorpe, kalendar author or owner, was more likely to have been the former owner of the 'Equatorium quondam mag. Ric. Thorpe' preserved in the Library of the Austin Friars, York (M. R. James, 'The catalogue of the library of the Augustinian Friars at York, now first edited from the manuscript at Trinity College, Dublin', in Fasciculus Joanni Willis Clark dicatus, Cambridge University Press, 1909, p. 58, number 378) than was the Oxford Thorpe, as suggested by Emden.

See Black's description, op. cit., note 6 above, item 10. 


\section{Linne R. Mooney}

The leaves of this booklet measure $293 \times 205 \mathrm{~mm}$. Initials are touched with red, tables are executed in red and brown inks, and the orbs in the eclipse tables are yellow-gold and black. The human figure on 9 r ("Zodiac Man") is crudely drawn but carefully executed, and coloured with red, green, blue, grey, and brown inks. The body and limbs have been shaded to give the figure a three-dimensional appearance. The right margin of folio $9^{\text {' }}$ has been badly worn, or rubbed, so that the text of column $c$, that is, lines 57-136 of "Compendium", is illegible except under ultraviolet light. The name of "Thomas Longland de Fastonsley", ' presumably an owner, has been written on folio $11^{v}$ in a hand of the fifteenth or early sixteenth century.

The second codex, MS Sloane 610 (hereinafter S) comprises a collection of medical recipes and the "Compendium of astrological medicine". The manuscript has thirtyfive vellum leaves measuring $190 \times 142 \mathrm{~mm}$., in four gatherings of eight (with 4.7 missing) and four flyleaves at the beginning. The second flyleaf has been cut out, and another added after the fourth. They have been included in the foliation as folios 1 to 4. The flyleaves were probably originally blank, but to them have been added pentrials (f. $1^{r}$ ), hastily written recipes (ff. $1 \vee-2$ ), a prose text on the diet appropriate to each month, and days in each month considered unlucky for bloodletting (ff. $3-4$ ), ${ }^{10}$ in a hand of the fifteenth century, and the owner's name (now erased and illegible) followed by ys boke in a fifteenth-century hand (f. 4 ). The main part of the book (ff. $5^{r}-35^{v}$ ) begins with the "Compendium" (ff. 5-6r), which is followed by a collection of remedies entitled, Here biginnen medicines for alle manere euelis, the whilke gode leches drowon out of bokes, that Galion, Aschephus [sic] and Ypocras hadde and vsude lechecraft, and wrote hem in boke on this maner wyse (ff. $6-35^{\mathrm{v}}$ ). Both of these texts are written by one hand, a fifteenth-century textura semi-quadrata, written in grey-brown ink with blue and red decorated initials and extensive rubrication. The "Compendium" is written as if it were prose, but with the first initial of each couplet touched with red ink. At one time, the book belonged to "W. Fouler", who wrote his name on folio 2 ?

Both texts of the "Compendium", but especially that of A, exhibit an orthography and morphology characteristic of the North of England. In the Sloane text are also found some examples of East Midlands orthography and vocabulary. ${ }^{11}$ The northern provenance of $\mathrm{A}$ is supported by the other contents of the manuscript. The kalendar of Richard Thorpe begins on folio 2 with the heading, Universis veras solis et lune conjunctiones temporaque eclipsium solarium et lunarium in $.4^{\circ}$. ciclis ab anno $X p^{\prime} i$ .1387. inchoante scire desiderantibus, Frater Ric'us Thorpp' Augustinensis presens opusculum inter alias scolasticas solicitudines votorum faciliter delatatum. This Augustinian friar is probably the Ricardus de Thorpe or Ricardus Thorpe, donor of four books (including two on astrology or astronomy) to the library of Augustinian

\footnotetext{
II rely on Black for the reading of Fastonsley, since now only the $F$ is distinguishable.

${ }^{10}$ See explanatory notes below, lines 106-113.

"Both texts use are (spelled $a r$, are, er) as present indicative third person plural of "to be", and occasionally use the $-n d(e)$ present participle ending. Both use Northern spellings ilk, whilk, aght, augte, walde. Ashmole also spells sall, haf(e), for-gif, be-hofis, lif, Quoso, slaw, ane, langer, bath, and strang, and uses tham as the third person plural pronoun. Sloane uses Midlands or East Midlands spellings honde and (occasionally) rygth, and vocabulary, bretheler (see explanatory notes, line 32).
} 


\section{A Middle English verse compendium of astrological medicine}

Friars at York, as noted in the 1372 catalogue of that library edited by M. R. James, ${ }^{12}$ The "Regule Eboracensis" added to folio $8^{v}$ in the fifteenth century also suggest a northern provenance.

The date of the original composition of the "Compendium" was probably the last third of the fourteenth century. The earlier surviving version, A, was probably written between 1387 and 1400. The kalendar of Richard Thorpe for the years beginning 1386 or 1387 gives the earliest date at which the manuscript could have been written. The inclusion of the table of phlebotomy of "Magister Johannis de Mirapice" (John Mirfield, whose major work, the Breviarium Bartholomaei is dated 1387) on folio $11^{\mathrm{r}}$ corroborates this earliest date for the manuscript. Gunther assigns the date 1386 to the volvelle (f. 1 ), of which an illustration is included in his Early science in Oxford. ${ }^{13}$ The original composition of the "Compendium" probably followed that of John of Burgundy's treatise on the plague (1365), cited in line 131, unless this portion of the poem was added later. The probable date of original composition is, then, some time between 1365 and 1400 , and quite likely before 1387 .

The "Compendium" may have begun its existence as a verse treatise on the influences of the heavenly bodies upon man - itself a compilation of information circulating independently in both Latin and English texts - and, like the Latin Regimen sanitatis Salernitanum to which it is related, ${ }^{14}$ only grew into the surviving "Compendium" through years of scribal revision and amplification. Changes of person, number, and rhyme scheme, and variants between the two extant texts show how the excerpts, paraphrases, and translations from various sources were brought together, either by the original compiler or by subsequent scribes.

Changes of person and number may indicate the boundaries between originally independent portions of the verses, or between original sources whose person and number the scribe neglected to bring into harmony with one another in the process of translating or compilation. Lines 1-8 combine a first person plural (we, us) with a third person singular (man, line 5). Lines 9-26 use the third person (man, men, he). Lines 27-35 return to the first person plural (us, we), changing at line 36 to a first person singular (I) addressing a second person (the, thou), which continues to line 81 . Lines 82-105, which occur in S only, and 106-110, use the third person (man, he, wymmen, men, Who-so), and 111-113 use the first person singular (I) with the third person (he, him). The rest of the poem, lines 114-134, returns to the first person singular (I) addressing a second person (thi, thu, the). The Ashmole text continues in these persons in the colophon, lines 135-136.

Changes of rhyme scheme also offer evidence of compilation from several sources.

12 James, op. cit., note 7 above, pp. 2-96. Thorpe is named in the heading of the catalogue (James, p. 19); books donated by him are numbers 104, 105, and 378, 389 under the subheading Astronomia et Astrologia (James, pp. 28,58, 60); he also copied excerpts from Nicholas de Lyra in another MS, numbered 51 (James, p. 22 and note p. 85 ).

${ }_{13}^{13}$ R. T. Gunther, Early science in Oxford, Oxford, Clarendon Press, 1923, vol. 2, p. 235.

${ }_{14}$ In his History of medicine (trans. Ernest Playfair, 2 vols., Oxford University Press, 1910-25, vol. 2. p. 31), Max Neuburger suggests that the Regimen sanitatis Salernitanum became a "metric encyclopedia of medicine" through centuries of additions and amplifications. The 'Compendium of astrological medicine' includes the earliest known Middle English verse translation of lines of the Regimen, at lines 13-20 (see explanatory notes below). 


\section{Linne R. Mooney}

For instance, the first four lines, rhyming $a b a b$ instead of couplets like the rest, may have been added after the original composition of the poem, in a source common to these two surviving texts. Other variants from the couplet scheme occur in lines 67-70, in $\mathrm{S}$ only, where the rhymes are tounge, honde, loungis, fynde, loosely $a b a b$, and lines 71-75 in both texts, rhyming nerus, bleddirs, hamys, anclys and helys, loosely aaaaa. These may indicate where the prose or another rhyme scheme of an original source for this portion of the poem was incompletely changed to couplets.

Variants in the two extant texts of the "Compendium" offer indisputable evidence of scribal alteration or amplification. Only A has lines 43-56, listing the days of the moon auspicious or perilous for letting blood, and lines 114-122, listing the best days in each month for bloodletting; and only $S$ has lines $82-105$, naming the specific veins to be opened for specific ailments. The scribes of these texts, or those of their sources, have added these lines as amplification of the text, from their own knowledge or, more likely, from another manuscript. In the case of the Ashmole scribe (or his source), only the merest attempt has been made to make these lines conform to the rhyme and metre of the rest. He has added the lists of dates, not really as part of the poem, but almost as a gloss on the text. Both scribes have allowed incomplete rhymes in these added portions, in $\mathrm{A}$ at lines 51-52 (thirty, abide) and line 118 (kalend $x v$ ), an incomplete couplet (lines 119-120 and 121-122 rhyme loosely); in S at lines 98-99 (thombe lies, lounge), where thombe and lounge may have been the original or intended rhyme, with lies to the thombe in line 98.

Taken together, these variants in personal pronouns, rhyme, and content suggest blocks of lines from originally independent sources in verse or prose: lines $1-4$, with rhyme scheme $a b a b$; lines 13-20, being a direct translation of eight lines of the Regimen sanitatis Salernitanum; ${ }^{15}$ lines 33 or $35-40$, with an abrupt change of person at the beginning of a portion of the poem (the three perilous days) which circulated both in other compilations and independently; 16 lines $41-42$, occurring in S only, and 43-56 in A only; lines 57-75 and possibly also 76-81, having content which circulated independently (the influence of the zodiac over parts of man's body) ${ }^{17}$ and problems of rhyme and line count at lines 67-75; lines 82-105, occurring in S only, and lines 114-122, in A only.

These are clear traces of the compiler's or composer's work. He has taken bits of information relative to his subject from several sources, sometimes translating verbatim from Latin verses, at other times probably paraphrasing and abridging Latin or vernacular sources, and converting the whole into the couplet scheme he has chosen for his work. It is now impossible to determine how much of the text as we have it represents the original composition, how much was added in subsequent copyings. Portions with different rhyme schemes, or where the rhyme fails altogether, are more likely to have been added, for most of the lines are true to the tetrametre couplet

\footnotetext{
15 See explanatory notes to lines $13-20$.

${ }^{16}$ The warnings about three perilous days for letting blood or eating gooseflesh also appear in the Regimen sanitatis Salernitanum, lines 304-307 (edited by Alexander Croke, Oxford, Talboys, 1830, 119-148). They are also named in the Venerable Bede's (spurious) De minutione sanguinis, sive de phlebotomia, in J. P. Migne (editor), Patrologia ecursus completus, series prima Latina. Paris, 1844-90, vol. 90, col. 960 . See explanatory notes to lines 37-40 for other Middle English texts.

${ }^{17}$ See explanatory notes, lines 65-75.
} 


\section{A Middle English verse compendium of astrological medicine}

scheme. Portions found in only one of the extant versions were probably added either by the scribes of those manuscripts or their sources - although lines on veins to be opened for bloodletting (82-105) may have been omitted from $A$ for lack of space and because that subject is treated elsewhere in the manuscript.

This compendium gave access to the received knowledge of astrological medicine in summary form for the rapidly growing literate public who were eager for learning of any kind. The short form made it easier to copy, or cheaper to have copied; and also made it easier to memorize for those who were looking for a "veneer of knowledge", 18 or for knowledge they could have at hand without reference to a written text. ${ }^{19} \mathrm{By}$ offering the knowledge of the ancients in popular form, it bridged the gap between the lore of the illiterate and the learning of the literate in the century in which many Englishmen were making the transition from the one group to the other.

The text of the "Compendium of astrological medicine" from Oxford. Bodleian Library, Ashmole 210, Part I, is edited below. Editorial procedure includes square brackets enclosing editorial emendations, with modern capitalization and punctuation. Medieval spelling, including the use of $u$ and $v$, has been preserved, except that medieval thorn has been written th, yogh has been written y or $\mathrm{g}$, where appropriate. Hyphens have been added to join affixes to roots, as in a-corde, with-outyn, with-in. bi-twene, be-falle. Lines which occur in only one of the surviving MSS are marked with a letter A or S, accordingly, in the left-hand margin. Below the text is an apparatus criticus and a set of explanatory notes appears at the end. The textual notes give variant readings from the Sloane MS, except where otherwise indicated.

\footnotetext{
${ }^{18}$ Rachel Hands, 'Horse-Dealing lore, or a fifteenth-century "help to discourse"?', Medium Aevum. 1972, 41: 237 , calls such works "'help[s] to discourse' of an ambitious citizen . . who needed a quick and easy method of acquiring a veneer of knowledge."

19 On the practice of composing medical texts in verse for ease of memorizing, Claudius F. Mayer ("A medieval English leechbook and its fourteenth-century poem on bloodletting', Bull. Hist. Med., 1939, 7 : 387) writes, "There was much new to learn, and the medieval student had to memorize a lot. Already the Salernitan School tried to help students by putting its doctrine into verses. Many other medical poems were written for the same purpose."
}

\section{THE COMPENDIUM OF ASTROLOGICAL MEDICINE}

God made all mankynd that lyues on the erthe

Of iiij elementys, als we in bokys rede:

Of fyre \& of ayre, of watir \& of erthe,

That gendirs in vs humors, als Arystotille vs lers.

Blod reynes in man at mydnygt, fleume in the mor[nyng],

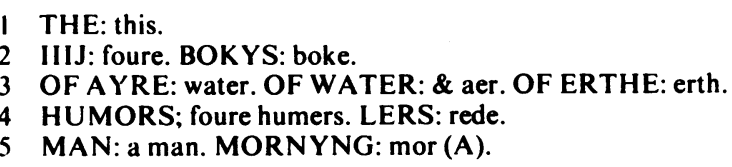




\section{Linne R. Mooney}

Colericus comys at none, malancole in the euyng;

And of thir iiij homers comys qualites sere,

After that thai haue mygt in man \& powere.

Sanguine is the fyrst, the ij fleumatyk;

The iij is malancole, the iiij coleryk.

Of thes iiij humors ilk man is made,

Bot all is nogt in lyke of qualite \& state:

Ffor iocund \& amerous \& laykand the rede is \& mery,

Ffleschely enowhe \& synghand, myld \& full hardy.

The whit is splepand \& slaw \& redy to spit,

Als fat is his face \& dull is his wit.

The gul is a gyloure, crabid \& hardy;

Quaynte \& full large he is, dry \& wily.

The blak is a chynche, drery, \& full of gyle,

Proude \& full couetus \& couert he is in wyll.

And rygt als men er nogt manard eftir ane,

So ilk man is of sere qualites of flesche \& bone.

Of iiij he is made, bot ane sall chefe be;

And fayle $j$ of the iiij, leue may nogt he.

Ffro qualites rote or on homer fayle,

[Man] my[ni]stirs medycyn to lok what may auayle.

Galyen the god leche contriued blode late

For voydyng of ill homer \& mendyng of state.

That nedis vs to wyt how we sall do

When corupcion of ill homer coms vs to.

For ay the langer we lyue, we er wayker,

And schorter be oure leueng \& frelir of mater.

Also vs nedys to wit when we sall blede,

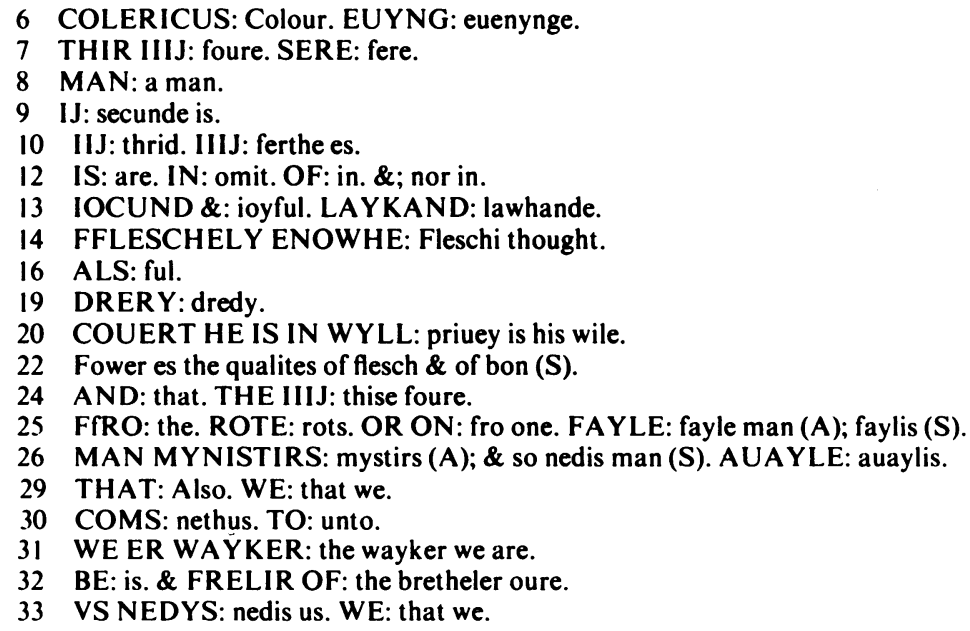




\section{A Middle English verse compendium of astrological medicine}

That the tyme of the mone [a]-cord wyth the dedes.

For sum tyme is gud \& sum tyme is ill,

The whilc I sall schew, for drede \& perill:

The last kalend of December, the [viij] of Aueryll,

The j day \& the last of August; this iiij er ill,

Ffor if thu lat the blud this days \& ete of a guse,

Wyth-in fourty days thu sall dy or be leprus.

$S$ The thridday after prime is ille wyth-outen were,

S In Ionis lyf of Beuerley that may thou lere.

A The first, the seuent, the thrittend ay,

A xiiij, \& xvij, \& xxiiij ay,

A $x x v j, x x v i j, x x i x$, tak if thu may,

A For thei er best of ilk mon, for sothe I the say.

A The secund mon, the $v$, the vj, the ix,

A The $x, x j$, the $x i j, \&$ the $x i i i j$,

A $x v, x v j, x v i i j, \& x i x$;

A The $x$ is for-bed, the $x v$ at the ende;

A xxviij is noght gude, ne at the $x x x$;

A \& er thu bled in tha that folus, I rede the a-bide:

A The iij day \& the iiij, \& the xviij als,

A \& ij \& $x x$ is perilus, \& so $x x i i j$ is.

A Thus may thu wele se \& persayue be skill

A That in ilk moneth is days bath gud \& ill.

Yit ther is xij syns in the zodyak spere

That er synid to the xij partys of the lyms sere,

Ffor if thu leche that lyme whil the [mone is] in the sygn[es],

Thu sall late or neuer bryng it to drynnes.

The mone compas tham all in aght $\& \mathrm{xx}$ days,

And in a syn regnes, als gret clerkis sayes,

Ij days \& viij oures be-for the moneth ende,

And turnys agayn to the fyrst, that Aries es kend.

The first sygn of the spere is cald Aries,

A-CORD: cord (A). WYTH: to. DEDES: dede.

ILL: yuel.

I SALL SCHEW: schal I schew the. \&: of.

KALEND: kalendes. VIIJ: XVIIJ (A); eygte (S).

J: furste.

ETE: etist.

FOURTY DAYS: fourtiday.

THE: omit.

SYNID: signes. THE: thi. SERE: fere.

59 THAT: thi. WHIL THE MONE IS IN THE SYGNES: whane the sone risus. MONE IS (A):

(indistinct; three minums and $s$, with a line over all). SYGNES (A): sygn (runs off edge of page).

60 SALL: schalt. TO DRYNNES: to the driwes.

61 Thou compassis hem alle in augte \& twenti dayes (S).

62 AND IN A SYN REGNES: \& ilke signe lenges.

64 AND TURNYS: In so turnes it. FYRST: firste kynde (kynde expunged). 
That kepis thi hede, thi faces, \& thi [ners].

Thi nek, thi scroupe \& thi tong kepis Taurus;

Gemini both thi hend kepis \& thi schuldirs.

Cancer wardis thi brest, the lungys, \& the splen;

Ffor the stomak \& the bak Leo sall defend.

Virgo the wambe [\&] the synis; Libra the reynis \& neth[irs];

Scorpio the yerd \& wombe, the aght \& the bleddirs;

Sagittarius the thes, the synus \& the hamys;

Aquarius the knese, leggys, \& the anclys;

Pisces has bothe the fete $\&$ also the helys.

Theofyll witnes is [that] I sall say:

A man dyed sudanly wyth-in the vij day,

Ffor he let hym blode vnkyndly for the suyna[cy]

When the mone was in syng of Gemini;

And ther-for be auysid all tyme of yere

That the lyme that sall blede \& the mon in the syng be [fere].

A man may be laten blod in two \& twenti stedis,

$\mathrm{S}$ Of the whilke in the heuyd are two faste behinde the eris:

$\mathrm{S}$ On thise schal he blede that may not here ne herke;

S \& two in the thunwonges schal blede for hede werke.

$\mathrm{S} \quad$ On in middis the fronte for the lepour \& for the goute, sey I;

$\mathrm{S} \&$ on the nose ende, for the fransy.

$\mathrm{S}$ Two in the side of the hed for faute of seyng;

S \& two bi the thropiss for wynde \& ondying.

S Two aboue the lippis schal blede for the flewme,

S \& two undirnthe for flayng \& for rewme.

$S \quad$ Two under-nethe the tunge for the sqwnaci;

S \& in the hed are no mo to blede, sothli.

S But in either arme is fyue, of the wilke thre are principal:

S The hed ueyne, the splene ueyne \& right ueyne a-cordis to the coral.

66 KEPIS: wers in. FACES: face. NERS: nors (A); neres (S).

67 Taurus hath thi nek, thi scroupe, \& thi tounge (S).

68 Gemini thi schuldris \& also thi honde (S).

69 WARDIS: hath. THE LUNGYS \& THE SPLEN: thi splene \& thi loungis.

70 THE STOMAK: stomac. DEFEND: fynde.

71 WAMBE \&: wambe (A). NETHIRS: neth (runs off page) (A); nerus (S).

72 \& WOMBE: the womb. AGHT: ache haunches.

73 THES: tos. SYNUS: synews.

74 LEGGYS: thi legges. THE ANCLYS: thi nancles.

75 HAS: hath. THE FETE: thi fete. THE HELYS: thi helis.

76 WITNES IS: witnesses. THAT: at (A).

77 DYED: dieth. SUDANLY: materiales. VIJ: seuent.

78 VNKYNDLY: unwyseli. SUYNACY: suyna (runs off page) (A); sqwynaci (S).

79 SYNG: the signe.

80 AUYSID: uised. YERE: the yere.

81 FERE: (off page) (A). 
S Cephalica ueyne for the hed; basillica ueyne for the splene;

S For al the bodi take coral, that lyes hem bi-twene.

S Cardica for the cardiakle, that to the thombe lies;

S Cela to litil finger, that mendis the lounge.

S Vnde[r] eyther wristis are two: domesca with-inne,

S That schal blede for the bleddir \& al that ther-inne;

S Vnder the ancles siluatica, the fot al with-oute,

S That schal blede for the sthatik \& also for the goute.

S Wymmen schul blede for the newe iwellis under the grete tos;

S Men for the quartayne \& for the emeraudes.

Quoso bledys on the rygt arme the xiiij day of March,

The $\mathrm{xj}^{\mathrm{d}}$ day of Auerill of lefte brace,

He sall neuer lose his sygt thorow goddes grace,

$\mathrm{Ne}$ yit if he blede on Saynt Geruase \& Prothase.

He that bledys the iiij \& the $v$ day in May,

He sall hafe na feuers that yer, for soth I sa[y].

I rede that ye that has the wild gout,

In Sant Lambert Day yer lat the blerd out.

A The xviij \& iij kalend, the ij nonas Feueryere;

A The iiij \& the last kalend of Mercce er two sere.

A Yit the iij kalend \& the iiij of Auerill,

A The xij of May \& the xviij of Iuny is nother ill.

A The iiij ides of Iuny, Iuly kalend $x v$,

A The kalend of Auguste, the iij nonas of Septembir,

A The xj kalend \& the $v$ nonas of Octobir,

A Nonas of Nouenbir, the iiij kalend of Decembir:

A Ffor thei er abill to bledyng that I haf nenyd her.

Lig lang in thi bed when thu thynkys to blede,

Loke thu wirk nothyng for nokyn nede;

Ffor lyghtly may thu meng gud blud \& ill -

To blend gud blod wyth ill it war perill.

The dismall days er nogt ill for thai wer first s[o cald];

When God chastid Egypcians that bow hym ne wald.

100 UNDER: unde (S).

106 BLEDYS: bledeth. XIIIJ: first.

$107 \mathrm{XJ}$. ellefte. OF LEFTE: on the lefte.

109 YIT IF: yif. SAYNT GERUASE \&: Geruaths Day \& on.

110 He that bledis on the ferthe day or the first of May (S).

111 He schal neuere haue the fyuere, for sothe os I the say (S). SAY: sa (runs off page) (A).

112 THAT YE: him.

113 IN SANT: on Sen. YER: omit. BLERD: blod.

124 NOKYN: nonkenes.

125 GUD: the gode. \&: with.

126 BLEND: blede. WYTH ILL: omit. PERILL: a peryle.

127 FIRST: omit. SO CALD: s (runs off page)(A).

128 In hem God chastised the Gipcians that him bouwe ne walde (S). 
If the pestelence com, on foure splenis sall the $b$ [lede]

Wyth-in xxiiij hours \& lyf wyth-outyn drede.

Ion of Burgoyn says thus in his treticys,

$\&$ redes the thus to do $\&$ on this wyse:

The be-hofis bled sum all iiij till thu be neuer mad wrath,

And synthen wyth vineger \& salt salle frete thi fete.

A I haue sayd als I hafe sens; for-gif me if it be [wrang],

A And excuse me sere frend, for the mater was hard \& strang.

129 SALL THE: schaltow. BLEDE: $b$ (runs off page) (A).

130 XXIIIJ: foure \& twenti.

132 \& ON THIS: in almanere. (wrath, last word of line 133, added after end of this line in A.)

133 The bus blede on alle foure, thi balis for to bete (S).

134 \& SALT SALLE: harde. FRETE: frote.

135-6 (colophon) Fayr be-falle the blod latere (S).

135 WRANG. (off page) (A).

\section{EXPLANATORY NOTES}

1-4 These lines, rhyming $a b a b$, may have been added as an introduction (see above). In line 4, $S$ gives an incorrect form of the third person singular indicative, rede, to maintain the rhyme, while A allows the rhyme to fail with the grammatically correct lers.

4 ARYSTOTILLE. In De Caelo, Lib. III, Aristotle argues that the four elements are the simple bodies from which all other bodies are composed, but he does not mention the four humours specifically.

7 SERE. Separate, distinct. S also writes fere for sere at line 58. Perhaps ' $f$ ' and 's' looked alike in the hand of his source.

13-20 Translation of Latin Regimen sanitatis Salernitanum or Flos medicinae. The lines in Salvatore de Renzi's ed. of Flos (Renzi, Henschel and Daremberg (editors), Collectio Salernitana, 5 vols., Naples, Filiatre-Sebezio, 1852-59, vol. 1, pp. 483-484) are as follows:

Largus, amans, hilaris, ridens, rubeique coloris,

Cantans, carnosus, satis audax, atque benignus.

Hic somnolentus, piger, in sputamine multus.

Hebes ei sensus, pinguis facies, color albus.

Hirsutus, fallax, irascens, prodigus, audax,

Astutus, gracilis, siccus, croceique coloris.

1185

Invidus et tristis, cupidus, dextraeque tenacis,

1196

Non expers fraudis, timidus, luteique coloris.

1197

13 LAYKAND (A). Playing; LAWHANDE (S). Laughing. THE REDE. The sanguine man.

14 FLESCHELY ENOWHE (A). Lat. carnosus (Flos 1179); FLESCHI THOUGHT (S). Considered fleshy? Prob. A is correct. SYNGHAND. Singing.

15 THE WHIT. The phlegmatic man. SPLEPAND. Prob. error for slepand, sleeping.

16 ALS ... The sense implies a reading of the Latin associating pinguis with facies as in Renzi's punctuation, line 1191; other verses on the complexions (Rossell Hope Robbins (editor), Secular lyrics of the fourteenth and fifteenth centuries, 2nd ed., Oxford, Clarendon Press, 1955, pp. 72-73) translate as if the comma came between pinguis and facies: "Fatt of kynde, the Flewmous man may trace,/And know hym best by whitnes of his face."

17 THE GUL. The yellow; that is, the choleric man. GYLOURE. A beguiler, deceiver (Lat. fallax, line 1184). CRABID. Angry, ill-tempered (Lat. irascens, 1184). 


\section{A Middle English verse compendium of astrological medicine}

18 QUAYNTE. Wise, skilled (Lat. astutus, 1185). LARGE. Lat. prodigus, (1184).

19 THE BLAK. The melancholic man. CHYNCHE. A niggard, miser; prob. trans. Lat. dextraeque tenacis (1196), literally, "having a tenacious right hand". DRERY. Lat. tristis (1196). DREDY (S). Fearful; Lat. timidus (1197) or pavidus (see note, line 20).

20 PROUDE. Some versions of Flos and Regimen have pavidus for Invidus in line 1196, and tumidus for timidus in line 1197. This must have been the reading in the source for this translation where proude $=$ tumidus.

21 This line may be read, "And just as men are not all of one disposition" (literally, "mannered after one").

24 May be read, "And if one of the four is lacking, he may not live."

25 ROTE. Rot, deteriorate; "From the time that one humour fails, the qualities deteriorate."

25-6 The scribe of A wrote man as if it were the last word of line 25; that it belongs in line 26 is clear both from the rhyme and from the sense of line 26 in the $S$ version.

27 GALYEN. Prob. on basis of Galen's Tegni or Ars Medica.

30 NETHUS (S). Forces, compels; “... when corruption of evil humour compels us to let blood"; or perhaps miswritten for neyus, "approaches", as in A, coms.

31 AYKER. Weaker, Northern and Northeast Midlands spelling.

32 SCHORTER BE OURE LEUENG. " ... the shorter the time we have yet to live." Northeast Midlands spelling. BRETHELER (S). Weaker, more fragile. This term associated with Northeast Midlands dialect (see Norman Davis, 'The language of the Pastons', Proc. of the British Academy, 1954, 40: 133).

37-40 Other Middle English warnings about three (or four) perilous days are found in Bodl. Addl. A.106, ff. $192^{\vee}-194^{\mathrm{r}}(I M E V 2131)$, lines 55-62, 73-90; in texts of thirty-two perilous days in the year in Bodl. Rawl. C.211, ff. 12 ${ }^{\mathrm{v}}-13^{\mathrm{v}}$, Camb. Trinity R.14.51, ff. $13^{\mathrm{r}}$ and $22^{\mathrm{r}}-23^{\mathrm{r}}$, and B. L. Sloane 1315, ff. $29^{v}-30^{v}$, lines 44-51; and in other collections, Bodl. Tanner 407, f. $11^{v}$, Nat. Lib. of Wales, Porkington 10, f. $1^{\mathrm{v}}$, and B. L. Sloane 213, ff. $106^{\mathrm{v}}-107^{\mathrm{v}}$. The most commonly named dates are 8 calends April, 1 calends August, and last calends December.

37 EYGTE (S). We may understand kalendes to follow this, as in the first half of the line. Last kalends Dec. $=$ Dec. 1; 8th kalends April $=$ March 25.

42 IONIS LYF OF BEUERLEY. Refers not to the Vita S. Joannis Beverlacensis, but to Bede's account of the life in Historia Ecclesiastica, Lib. V, Cap. III, in which John gives the warning against letting blood in the fourth day of the moon before healing a nun whose arm had become infected after bloodletting on that day.

45 TAK IF THU MAY. “. . . take [blood] [i.e. let blood] if you can”.

47-51 Perhaps all of these dates are to be read with is noght gude of line 51.

47 SECUND MON. The second lunar month?

51-2 The rhyme fails in these lines.

52 THA THAT FOLUS. ". . . those that follow".

54 IJ \& XX. Two and twenty, or, twenty-second.

59 LYME. Limb.

60 TO DRYNES. “... to the state of dryness"; i.e., "... you will never stop the flow of blood".

63 BE-FOR THE MONETH ENDE. Each sign rules for two days and eight hours in the course of the month.

64 TURNYS. This word is difficult to read in both versions, the siglum for 'ur' being indistinct in $S$ and the ' $u$ ' almost illegible in A. IT (S). The moon. ARIES. (The indirect object.) KEND. Naturally pertaining to; "And so it returns to the first (of the month) which naturally pertains to Aries". 


\section{Linne R. Mooney}

65-75 Middle English prose texts on this subject are found in Bodl. Ashmole 1477, Pt. I, p. 94;

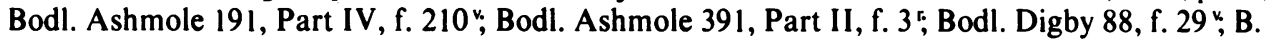
L. Sloane 100 , f. $36^{\mathrm{r}-\mathrm{k}}$, and Wellcome Institute 41 , ff. $15^{\mathrm{r}}-16^{\mathrm{r}}$. A verse treatment is included in John Lydgate's ‘A pageant of knowledge' (IMEV 3503 and 3651), lines 113-133.

66 WERS (S). Protects, defends. NERS, NERES. Ears.

67 SCROUPE. Scruff, or nape of the neck?

71 SYNIS. Sinews. REYNIS. Kidneys. NETHIRS (A). Lower parts? NERUS (S). Nerves.

72 YERD. Penis. AGHT. Poss. a misreading of haunches in a source common to A and S (?). In $S$, the scribe may be writing both mistake and correction: ache haunches. BLEDDRIS. Bladder.

76 THEOFYLL. Theophilus, a Byzantine Greek author of a work on urines which is included in the Articella, a collection well known in medieval English medical schools. (See Vern L. Bullough, 'Medical study at medieval Oxford', Speculum, 1961, 36: 607, note 74; and Charles H. Haskins, Studies in the history of medieval science, Cambridge, Mass., Harvard University Press, 1927, p. 369, note 63.)

77 MATERIALES (S). Material-less (?), i.e. without material cause.

78 SUYNACY. Squinacy, quinsy.

79 GEMINI. It is usually Taurus, not Gemini, which governs the throat (see line 67). This error was made in a source common to $\mathrm{A}$ and $\mathrm{S}$, and prob. in the original, for Taurus would not rhyme with sqwynaci.

81 FERE. Together, in common.

82-105 Instructions in veins to be opened for specific ailments circulated widely in the fourteenth and fifteenth centuries. For verse texts, see footnote 5 above. Short prose instructions include National Library of Wales, Porkington 10, f. 7 ; B.L., Sloane 963, f. 5 ; and Wellcome Institute Library 407, ff. 11-15.

82 THUNWONGES. Temples.

86 FRONTE. Forehead.

89 THROPISS. Poss. a mistake for thropple (Northern dialect), meaning gullet or windpipe. ONDYNG. Breathing (Midlands and Southern form of the Northern ande).

90 FLEWME. Phlegm, mucus; here prob. in the sense of morbid or excessive discharge thereof.

91 FLA YNG. Peeling back or removing skin. REWME. Rheum.

95 CORAL. The median vein.

99 CELA. Prob. a miscopying of Salva cella, the spelling of salva-tella recorded in a version of 'Bloodletting' verses (IMEV 3848), in Bodl. Ashmole 1477, Pt. I, pp. 96-98, line 67; the source of $\mathrm{S}$ may have used the same spelling.

100 DOMESCA. Domestica, saphena major.

102 SILUATICA. This name for the sciatic vein also occurs in several versions of the 'Bloodletting' verses (IMEV 3848), line 74.

103 STHATIK. (The second letter is thorn.) Prob. miswritten for sciatik, sciatica.

104 NEWE IWELLIS. New evils (?); poss. rel. to 'month evil', menstruation; cf. 'Bloodletting' verses (IMEV 3848) ed. Robbins, op. cit., note to line 16 above, pp. $77-80$, lines 79-80.

105 QUARTAYNE. Quartan fever. EMERAUDES. Haemmorrhoids.

106-113 These good days to let blood were also named in a Middle English monthly regimen of diet and good or evil days for bloodletting which survives in at least 13 MSS: Bodl. Ashmole 1477, Pt. I, pp. 95-96; Bodl. Rawlinson A.429, f. 92 ${ }^{\text {r-v; }}$ B.L. Arundel 359, ff. 


\section{A Middle English verse compendium of astrological medicine}

$15^{\mathrm{v}}-17^{\mathrm{v}}$; B. L. Sloane $540 \mathrm{~A}$, ff. $24^{\mathrm{r}}-25^{\mathrm{r}}$; Sloane 610, ff. $3^{\mathrm{r}-4^{\mathrm{r}}}$; Sloane 962 , f. $72^{\mathrm{v}}$; Sloane 963, ff. $3^{v}-4^{\text {r; }}$ Sloane 1315, Pt. II, ff. 30 $-32^{\text {r; }}$ Sloane 3160, Pt. II, f. $148^{r-v}$ and again at f. $151^{r-v}$; Wellcome Institute Library 41 , ff. $7^{-}-12^{v}$; Wellcome 404, f. $^{r-v}$ and again at $34^{r}-36^{r}$; Wellcome 405, ff. 67 $-71^{\mathrm{v}}$; and Wellcome 409, ff. 78 $-79^{\text {r. They }}$ are also named in other short texts on lucky and unlucky days, in Bodl. Addl. A.106, ff. 192 -194 r (IMEV 2131), lines 63-72; B. L. Sloane 213, ff. $106^{\vee}-107^{\text {; }}$; Bodl. Ashmole 1481, Pt. I.e., f. $25^{\text {*; }}$ and B. L. Sloane 540A, f. 24 ?

107 BRACE. Arm.

109 SAYNT GERUASE ... . The day of SS. Gervasius and Protasius, June 19.

112 WILD GOUT. Poss. "falling gout", epilepsy.

113 SANT LAMBERD DAY. Saint Lambert's Day, 17 Sept. YER (A). Poss. "in the year" or "every year"; or Northern dialect spelling of ye. BLERD (A). Prob. miswritten blood.

114 THE XVIIJ .... 18th and 3rd calends of Feb.= Jan. 15 and 30, respectively, in the Roman calendar. 2nd or Pridie nones of Feb. = Feb. 4.

115 THE IIIJ . ... 4th and last calends of Mar. = Feb. 26 and Mar. 1.

116 YIT THE .... 3rd and 4th calends April = Mar. 31 and 30.

118-21 4th Ides of June = June 10; 15th calend July = June 17; calends of Aug. = Aug. 1; 3rd nones Sept. $=$ Sept. $3 ; 11$ th calend Oct. $=$ Sept. $21 ;$ th nones Oct. $=$ Oct. 3 ; nones Nov. $=$ Nov. 5; 4th calend Dec. $=$ Nov. 28. See note to lines 127-8.

118 This line rhymes with neither 117 nor 119.

124 NOKYN (A), NONKENES (S). No kind of, not any.

125 GUD BLUD \& ILL. It was believed that ill or evil blood caused disease; if one bled on the days when good and bad blood were mixed (meng), one lost good blood as well as bad.

127-8 DISMALL DAYS. "The dies mali, evil, unlucky, or unpropitious days of the medieval calendar, called also dies Aegyptiaci, "Egipcian daies." The dies mali were Jan. 1, 25; Feb. 4, 26; Mar. 1, 28; Apr. 10, 20; May 3, 25; June 10, 16; July 13, 22; Aug. 1, 30; Sept. 3, 21; Oct. 3, 22; Nov. 5, 28; and Dec. 7, 22. They are said to have been called "Egyptian days" because first discovered or computed by Egyptian astrologers, though some medieval writers [including the author of the "Compendium"] connected them with the plagues of ancient Egypt." (Oxford English Dictionary, 'dismal days'.) Note that many of these dates correspond to those named as "abill to bledyng" in A, lines 114-122, above; the scribe must have misread his source, mistranslated or misunderstood (he does say that the mater was hard \& strang in the colophon, below).

129 FOUR SPLENIS. Perhaps a mistake for youre splene or foure stedes in a source common to $A$ and $S$; the latter (foure stedes) would correspond with line 133 (all iiij).

131 ION OF BURGOYN. John of Burgundy (fl. 1365), to whom is attributed a whole class of treatises on the plague. See Dorothea Waley Singer, 'Some plague tractates', Proc. $R$. Soc. Med.. 1916, 9: Part 2, History of Medicine, pp. 159-212; and Dorothea Waley Singer and Annie Anderson, Catalogue of Latin and vernacular plague tracts in Great Britain and Eire written before the sixteenth century, London, Heinemann Medical Books, 1950.

133-4 Rhyme fails in A, but maintained in S.

133 BUS (S). Northern dialect form of behoves. ALL IIIJ. Prob. the four places mentioned in line 129. TILL THU BE NEUER MAD WRATH (A). "Until you are too weak to anger" (?). THI BALIS FOR TO BETE (S). "In order to cure your woes or injuries (balis)".

134 SYTHEN. Afterward. FRETE (A), FROTE (S). Rub.

136 STRANG. Prob. "strong", in the sense of "arduous", rather than "strange". 